\title{
Is Radiotherapy Necessary for Stage 1 Testicular Seminoma?
}

\author{
Jung Ae Lee, M.D.*, Won Park, M.D., Ph.D.*, Do Hoon Lim, M.D., Ph.D.*, \\ Yong Chan Ahn, M.D., Ph.D.*, Seung Jae Huh, M.D., Ph.D.*, Jeong II Yu, M.D.*, \\ Han Yong Choi, M.D., Ph.D., Hyun Moo Lee, M.D., Ph.D. and Eun Yoon Cho, M.D., Ph.D. \\ Departments of *Radiation Oncology, ${ }^{\dagger}$ Urology, ${ }^{\ddagger}$ Pathology, Samsung Medical Center, \\ Sungkyunkwan University School of Medicine, Seoul, Korea
}

\begin{abstract}
Purpose: To report on the clinical outcome of patients with stage I testicular seminoma by postoperative radiotherapy (PORT) or surveillance after radical inguinal orchiectomy.

Materials and Methods: This study is a retrospective review of 32 stage I pure seminoma patients treated between 1996 and 2005 at the Samsung Medical Center. Twenty two of the patients were treated by PORT, which was directed at the paraaortic lymphatics with a median dose of 25.2 Gy in 14 fractions for 3 weeks. The 10 remaining patients were managed by surveillance. The median follow-up period was 96 months with a range of 24 to 155 months.

Results: Clinically, most patients presented with a testicular mass or discomfort. Two of the patients had a history of undescended testes. Pathologically, 23 of the patients had intratubular germ cell neoplasia with seminoma. Both recurrence-free survival (RFS) and overall survival (OS) rates of patients treated by PORT were $100 \%$. In the control group, 1 of the 10 patients suffered a para-aortic lymph node relapse. The RFS and OS rates of the surveillance group were $88.9 \%$ and $100 \%$, respectively.

Conclusion: No difference in survival was observed between the two groups. Moreover, symptom recurrence was only observed in 1 patient in the control group. The use of PORT may reduce the risk of relapse. With the availability of effective diagnostic and salvage modalities, surveillance monitoring may be considered for patients in good compliance.
\end{abstract}

Key Words: Seminoma, Radical orchiectomy, Radiation therapy, Surveillance

Introduction

Testicular germ cell tumors (GCT) account for 1 2\% of all male malignancies. These tumors are the most common malignancy among young men, with a median age at diagnosis of approximately 34 years old. Testicular seminomas account for $40 \sim 60 \%$ of all testicular GCTs, and $75 \%$ of the patients are diagnosed with stage I disease. Fifteen to $20 \%$ of patients with stage I disease have subclinical metastases, usually in the paraaortic lymph nodes. The incidence of testicular GCT has doubled during last three decades, with unknown etiology. ${ }^{1)}$ Despite the increased incidence, testicular

Submitted April 8, 2009, accepted May 7, 2009

Reprint requests to Won Park, Department of Radiation Oncology, Samsung Medical Center, Sungkyunkwan University School of Medicine, 50, Irwon-dong, Gangnam-gu, Seoul 135-710, Korea Tel: 02)3410-2616, Fax: 02)3410-2619

E-mail: wonro.park@ samsung.com seminoma is one of the most curable solid neoplasms, with a 5 -year cancer-free survival approaching nearly $100 \%$, due to remarkable treatment advances that began in the late 1970s. Postoperative radiotherapy (PORT) directed to the retroperitoneal and ipsilateral pelvic nodes is traditionally the standard treatment for patients with stage I seminoma. However, there is a trend towards decreased treatment intensity or even therapeutic abstention (i.e. surveillance) due to the risks of longterm treatment-related morbidity and a benefit of only $15 \%$ to $20 \%$ of the patients with subclinical disease. ${ }^{3)}$ The main concern of recent studies has been to maintain a high cure rate while minimizing treatment-related complications. The 1999 British Medical Research Council (MRC) trial TE10 $0^{4)}$ demonstrated that PORT is comparable to the classical dog-leg field, with lower toxicity when directed to the paraaortic field. The 2005 British MRC trial TE18 $8^{3)}$ demonstrated a dose equivalence between 20 and 30 Gy. Furthermore, according to the Princess Margaret Hospital, ${ }^{5,6)}$ surveillance results in an 
average recurrence rate of 15 to $20 \%$ with early detection of recurrences and a high salvage rate.

Hence, this retrospective study was conducted with the following objectives: (1) to analyze clinical characteristics of stage 1 adult testicular seminoma and (2) to identify future directions of treatment by assessing PORT versus active surveillance after radical inguinal orchiectomy.

\section{Materials and Methods}

We retrospectively analyzed 34 patients treated at Samsung Medical Center between January 1996 and September 2005 for stage I testicular seminoma. Medical records of all patients were reviewed according to the following: histologic diagnosis of pure seminoma after radical inguinal orchiectomy, clear spermatic cord resection margins, no clinical or radiologic evidence of regional or distant metastasis, and normal postoperative serum $\alpha$-fetoprotein (AFP) and $\beta$-Human chorionic gonadotropin ( $\beta-\mathrm{HCG})$ levels. Orchiectomy specimens were fully reviewed by one pathologist to confirm a diagnosis of pure seminoma. Radiologic exams included chest X-ray and computed tomography (CT) of the abdomen and pelvis, and were performed in all patients. Thirty two patients with pure seminoma except 2 spermatocytic seminoma patients were analyzed in terms of demographics, clinical characteristics, $\mathrm{T}$ stage, postoperative management, recurrence, and survival. PORT was administered after orchiectomy in 22 patients, and no adjuvant treatment was given to the 10 patients in the surveillance group. There were no specific criteria to divide patients into PORT or surveillance group. Surgeon's preference was mainly influenced on the subsequent treatment after orchiectomy. Radiotherapy was delivered to the paraaortic lymphatics, with a median dose of 25.2 Gy (range 24 $30.6 \mathrm{~Gy}$ ) at $1.8 \sim 2$ Gy per fraction and with 10 or 15 megavoltage photon. Paraaortic lymphatic pathway was covered from L1 to L5 vertebra. For left-sided tumors, the left renal hilum was included in the field. Toxicity evaluation was based on the Radiation Therapy Oncology Group toxicity criteria. For surveillance, patients underwent a regular outpatient follow up with a physical examination, serum tumor marker tests, chest $\mathrm{X}$-ray, and CT of the abdomen and pelvis. Statistical analysis was made using the Kaplan-Meier method, and relapse-free survival rates were calculated from the date of surgery.

\section{Results}

\section{Patient characteristics}

Table 1 lists the patient characteristics. The median age was 34 years old and ranged from 22 to 58 years. All patients underwent inguinal orchiectomy for testicular seminoma. The most common presentation was a scrotal mass or swelling in $29(90.6 \%)$ of 32 cases. Two of these patients also suffered from scrotal discomfort, and one of these 32 patients also suffered from abdominal pain. Two patients had a past medical history of cryptorchidism. Twenty-four of the 32 patients had intratubular germ cell neoplasia (ITGN) with pure seminoma. Preoperative serum $\beta-H C G$ levels were elevated in 7 of the 32 patients and were normal in the rest. Preoperative serum LDH levels were elevated in 10 patients, normal in 11 patients, and not measured in 11 patients. Initial serum AFP levels were within normal limits in all patients. Most of the patients had a T1 disease status. The median tumor size was $6 \mathrm{~cm}$ and ranged from 2.5 to $12 \mathrm{~cm}$. The median tumor size of patients treated by PORT was $6.8 \mathrm{~cm}$, and that for the control group was $5 \mathrm{~cm}$. Nineteen of 22 (86.4\%) PORT-treated patients and 6 out of $10(60 \%)$ control patients had a tumor larger than $4 \mathrm{~cm}$ (Table 1).

\section{Relapse and survival}

All patients were alive at a median follow up of 96 months (range, 24 155 months), which was measured from the date of orchiectomy (Table 2). The median follow up of two groups was different, 112 months (range, 35 155 months) for PORT group and 46 months (range, 24 119 months) for control group, respectively. The five-year RFS for all patients was $96.8 \%$ (Fig. 1). None of the PORT-treated patients had recurrent disease, and thus had a $100 \%$ RFS (Fig. 2).

One control patient developed a nodal recurrence in the left paraaortic area 27 months after orchiectomy. This patient was 40 years old with a $5 \mathrm{~cm}$ by $4.5 \mathrm{~cm} \mathrm{T1}$ stage tumor. Salvage chemotherapy with the combination of bleomycin, etoposide and cisplatin (BEP) was performed, and no evidence of disease was observed up to 18 months after treatment (Fig. 3).

To evaluate prognostic factors for recurrence, parameters including age, tumor size, and $\mathrm{T}$ stage were assessed, and none of the factors had a statistically significant influence on 
Table 1. Patients' Characteristics of Stage 1 Testicular Seminoma

\begin{tabular}{|c|c|c|c|c|}
\hline Parameter & Total $(\%)$ & PORT $^{*}$ group $(n=22)$ & Surveillance group $(\mathrm{n}=10)$ & p-value \\
\hline \multicolumn{5}{|l|}{ Age (years) } \\
\hline$<34$ & $14(43.8 \%)$ & $10(45.5 \%)$ & $4(40 \%)$ & \multirow[t]{2}{*}{$\mathrm{NS}^{\top}$} \\
\hline$\geq 34$ & $18(56.2 \%)$ & $12(54.5 \%)$ & $6(60 \%)$ & \\
\hline \multicolumn{5}{|l|}{ Site } \\
\hline Right & $13(40.6 \%)$ & $12(54.5 \%)$ & $1(10.0 \%)$ & \multirow{2}{*}{$\mathrm{p}<0.05$} \\
\hline Left & $19(69.4 \%)$ & $10(45.5 \%)$ & $9(90.0 \%)$ & \\
\hline \multicolumn{5}{|l|}{ Serologic marker } \\
\hline $\mathrm{bHCG}^{\dagger}$ & 7 & 5 & 2 & \multirow[t]{3}{*}{ NS } \\
\hline $\mathrm{LDH}^{*}$ & 10 & 7 & 3 & \\
\hline $\mathrm{AFP}^{\S}$ & 0 & 0 & 0 & \\
\hline \multicolumn{5}{|l|}{$\mathrm{T}$ stage } \\
\hline $\mathrm{T} 1$ & $29(90.6 \%)$ & $20(90.9 \%)$ & $9(90.0 \%)$ & \multirow{3}{*}{ NS } \\
\hline $\mathrm{T} 2$ & $2(6.3 \%)$ & $2(9.1 \%)$ & $0(0 \%)$ & \\
\hline $\mathrm{T} 3$ & $1(3.1 \%)$ & $0(0 \%)$ & $1(10 \%)$ & \\
\hline \multicolumn{5}{|l|}{ Tumor size } \\
\hline$<4 \mathrm{~cm}$ & $7(21.9 \%)$ & $3(13.6 \%)$ & $4(40 \%)$ & \multirow[t]{2}{*}{$p<0.05$} \\
\hline$\geq 4 \mathrm{~cm}$ & $25(78.1 \%)$ & $19(86.4 \%)$ & $6(60 \%)$ & \\
\hline \multicolumn{5}{|l|}{ ITGN $^{\|}$} \\
\hline Yes & $24(75.0 \%)$ & $16(72.7 \%)$ & $8(80.0 \%)$ & \multirow[t]{3}{*}{ NS } \\
\hline No & $5(15.6)$ & $4(18.2 \%)$ & $1(10 \%)$ & \\
\hline Unknown & $3(9.4 \%)$ & $2(9.1 \%)$ & $1(10 \%)$ & \\
\hline
\end{tabular}

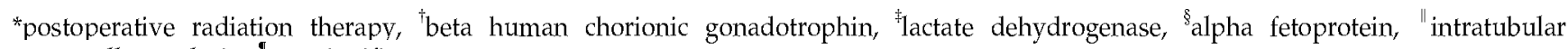
germ cell neoplasia, "not significant

Table 2. Survival Results of Each Group

\begin{tabular}{lccc}
\hline \hline & Total & $\begin{array}{c}\text { PORT* } \\
\text { group }\end{array}$ & $\begin{array}{c}\text { Surveillance } \\
\text { group }\end{array}$ \\
\hline Median f/u & 96 & 112 & 46 \\
(months)(range) & $(24 \sim 155)$ & $(35 \sim 155)$ & $(24 \sim 119)$ \\
5 year RFS $(\%)$ & $96.8 \%$ & $100 \%$ & $88.9 \%$ \\
5 year OS $(\%)$ & $100 \%$ & $100 \%$ & $100 \%$ \\
\hline
\end{tabular}

*postoperative radiation therapy, ${ }^{\dagger}$ recurrence free survival, ${ }^{\ddagger}$ overall survival

Fig. 1. Recurrence free survival of all patients.
Fig. 2. Recurrence free survival of each group.

\section{RFS (Table 3).}

In PORT-treated patients, radiotherapy morbidity was limited to Grade I acute gastrointestinal side effects, with nausea in five patients and vomiting in one patient. However all PORT-treated patients tolerated treatment with no interruption during radiotherapy. 
Fig. 3. Computed tomography of left paraaortic recurrence. (A) A nodal recurrence 27 months after orchiectomy in the left paraaortic area (arrow). (B) Complete remission state after salvage chemotherapy with the combination of bleomycin, etoposide and cisplatin (BEP).

Table 3. Prognostic Factor Evaluation for Paraaortic Recurrence

\begin{tabular}{|c|c|c|c|c|}
\hline Parameter & Number & $\begin{array}{c}5 \text { year } \\
\text { RFS }^{*}(\%)\end{array}$ & $\begin{array}{c}\mathrm{p} \text {-value } \\
\text { (univariate) }\end{array}$ & $\begin{array}{c}\mathrm{p} \text {-value } \\
\text { (multivariate) }\end{array}$ \\
\hline \multicolumn{5}{|l|}{ Age (years) } \\
\hline$<34$ & 18 & 100 & 0.2705 & 0.4035 \\
\hline$\geq 34$ & 14 & 92.9 & & \\
\hline \multicolumn{5}{|l|}{$\mathrm{T}$ stage } \\
\hline T1 & 29 & 96.4 & 0.9478 & 0.8456 \\
\hline $\mathrm{T} 2$ or $\mathrm{T} 3$ & 3 & 100 & & \\
\hline \multicolumn{5}{|l|}{ Tumor size } \\
\hline$<4 \mathrm{~cm}$ & 7 & 100 & 0.5892 & 0.4853 \\
\hline$\geq 4 \mathrm{~cm}$ & 25 & 95.8 & & \\
\hline
\end{tabular}

*recurrence free survival

\section{Discussion and Conclusion}

There is a wide variation in worldwide incidence of testicular seminoma, with the highest incidence in northern European countries and the lowest incidence in eastern Europe and Asia, which explains why almost all large studies are from western countries. There are few studies on Asian males with testicular seminoma. Our study may be the largest study regarding stage 1 seminoma in Asian patients, and may indicate a clinical direction for the treatment of this subset of patients in Asia.

Historically, early stage seminoma was treated with orchiectomy followed by inguinal and paraaortic radiotherapy, and sometimes included mediastinal radiotherapy. However, pro- phylactic mediastinal radiotherapy was not performed after the 1970s due to significantly increased cardiac mortality. ${ }^{7)}$ Zagars et al. from The University of Texas M.D. Anderson Cancer Center reported on the long term treatment-related mortality of 477 men with stage I or II testicular seminoma treated by postorchiectomy radiotherapy between 1951 and 1999." The cardiac and cancer standardized mortality ratio were 1.61 and 1.91, respectively, and were significant after 15 years of follow-up $(\mathrm{p}<.01)$. A significant risk of death resulting from cardiac disease or secondary cancers was observed among long-term survivors of PORT-treated seminoma patients. After the 1970s, the dog-leg field became standard and included paraaortic and ipsilateral iliac lymphatics with a $30 \mathrm{~Gy}$ dose at 2 Gy per fraction. The 1999 British MRC trial TE10 $0^{4)}$ compared the relapse rates and toxicity associated with paraaortic field or dog-leg field (30 Gy/15 fractions/3 weeks) for 478 men with stage I testicular seminoma. With the 3-year RFS over $96 \%$ and significantly reduced hematologic, gastrointestinal, and gonadal toxicity, the paraaortic field only is comparable to the classical dog-leg field, if the lymphatic drainage is undisturbed. However, the paraaortic field resulted in a slightly higher risk of pelvic recurrence. Importantly, the median time to recovery in sperm counts was 13 months with the paraaortic field and 20 months with the dog-leg field if sperm counts were normal before radiotherapy, and was 24 and 37 months, respectively, if sperm counts were abnormal before radiotherapy. Also, the 2005 British MRC trial TE18 ${ }^{3)}$ 
demonstrated a dose equivalence between 20 and $30 \mathrm{~Gy}$. Two dose schedules of $20 \mathrm{~Gy}$ in 10 fractions or $30 \mathrm{~Gy}$ in 15 fractions in 625 patients with stage I seminoma were evaluated and, 10 and 11 relapses, respectively, were reported in the $30 \mathrm{~Gy}$ and $20 \mathrm{~Gy}$ groups with a median follow up of of 61 months. Reductions in morbidity enabled patients to return to work more rapidly, with $5 \%$ moderate to severe lethargy in patients treated with 20 Gy compared to $20 \%$ in patients treated with 30 Gy 4 weeks after PORT. Thus, there is a shift towards decreasing treatment morbidity. More recently, a surveillance strategy has begun overtaking PORT as a treatment modality, due to radiation-related late complications such as secondary malignancies ${ }^{7)}$ or infertility. The study from Netherlands ${ }^{8)}$ with median follow up of 7.7 years for 1909 testicular cancer patients has shown that the relative risk of gastrointestinal malignancies increases after radiation therapy or radiation therapy plus chemotherapy and is greatest after 10 years. An excess of soft tissue sarcoma has also been observed in other study. ${ }^{9)}$ The Princess Margaret Hospital ${ }^{5,(6)}$ and Danish Testicular Cancer Study Group ${ }^{10)}$ have reported on the surveillance strategy with average recurrence rates of 15 to $20 \%$. Early detection of recurrence and high salvage rates make this strategy feasible. In the current study, PORT was directed to paraaortic lymphatics with a median radiation dose of 25.2 Gy. Radiotherapy gave excellent results that were comparable with other clinical series. One of 10 patients managed by surveillance had recurrence with a RFS of $88.9 \%$. However, the median follow up of two groups was different, 112 months (range, 35 155 months) for PORT group and 46 months (range, 24 119 months) for control group, respectively. Although the majority of relapses are known to occur within 2 years after surgery, the recurrence rate of surveillance group may increase with longer follow up because control group had shorter follow up period than PORT group. There was no survival difference between the two groups. PORT may reduce the chance of recurrence, although there was no statistical significance.

Prognostic factors for recurrence have been studied often. ${ }^{6,11)}$ The size of the primary tumor $(\leq 4 \mathrm{~cm}$ vs. $>4 \mathrm{~cm})$ and invasion of the rete testis are statistically significant prognostic factors for relapse in the pooled analysis of 638 patients from the four largest surveillance studies." ${ }^{(0)}$ Also, the second Spanish Germ Cell Cancer Cooperative Group reported a prospective study of 314 patients. ${ }^{11)}$ Tumor size $(\leq 4 \mathrm{~cm}$ vs. $>4 \mathrm{~cm})$ and rete testis involvement were also risk factors for relapse, and patients without these risk factors were managed by surveillance. This risk-adapted management may be a reasonable treatment paradigm. In our series, the recurrence was only observed in one patient managed by surveillance who had a tumor of $5 \mathrm{~cm}$. However, we can not conclude that tumor size is the most important factor of regional recurrence or that PORT is needed for large tumors due to the small sample set, and there were no statistically significant risk factors. Currently, PORT is applied to the patients with stage I seminoma with lymphovascular invasion in our institution.

Meanwhile, because chemotherapy is effective for more advanced disease, several studies analyzed the use of chemotherapy for stage I seminoma. In the 2005 British MRC trial TE19, ${ }^{12)}$ comparable outcomes were achieved with a single dose of carboplatin or PORT. The 3-year relapse-free survival was $95 \%$ with carboplatin treatment and $96 \%$ with PORT.

In conclusion, PORT may reduce the risk of relapse, especially for larger tumors. There were no significant prognostic factors due to small sample size. However, it could be a reasonable approach to apply PORT according to the risk factors and further study should be needed. With the availability of effective diagnostic and salvage modalities, surveillance may be considered for patients with good compliance.

\section{Acknowledgments}

All the authors participated in the design, execution, and analysis of this paper and approved the final version. There is no conflict of interest in connection with this paper and the material described is not under publication or consideration for publication elsewhere.

\section{References}

1. McGlynn KA, Devesa SS, Sigurdson AJ, Brown LM, Tsao L, Tarone RE. Trends in the incidence of testicular germ cell tumors in the United States. Cancer 2003:97:63-70

2. Jemal A, Siegel $R$, Ward $E$, Murray $T$, Xu J, Thun MJ. Cancer statistics, 2007. CA Cancer J Clin 2007:57:43-66

3. Jones WG, Fossa SD, Mead GM, et al. Randomized trial of 30 versus 20 Gy in the adjuvant treatment of stage I 
Testicular Seminoma: a report on Medical Research Council Trial TE18, European Organisation for the Research and Treatment of Cancer Trial 30942 (ISRCTN18525328). J Clin Oncol 2005;23:1200-1208

4. Fossa SD, Horwich A, Russell JM, et al. Optimal planning target volume for stage | testicular seminoma: A Medical Research Council randomized trial. Medical Research Council Testicular Tumor Working Group. J Clin Oncol 1999; 17:1146

5. Choo R, Thomas G, Woo T, et al. Long-term outcome of postorchiectomy surveillance for Stage I testicular seminoma. Int J Radiat Oncol Biol Phys 2005;61:736-740

6. Warde $P$, Specht $L$, Horwich $A$, et al. Prognostic factors for relapse in stage I seminoma managed by surveillance: a pooled analysis. J Clin Oncol 2002;20:4448-4452

7. Zagars GK, Ballo MT, Lee AK, Strom SS. Mortality after cure of testicular seminoma. J Clin Oncol 2004;22:640-647
8. van Leeuwen FE, Stiggelbout AM, van den BeltDusebout AW, et al. Second cancer risk following testicular cancer: a follow-up study of 1,909 patients. J Clin Oncol 1993:11:415-424

9. Jacobsen GK, Mellemgaard A, Engelholm SA, Moller $\mathrm{H}$. Increased incidence of sarcoma in patients treated for testicular seminoma. Eur J Cancer 1993:29A:664-668

10. Daugaard G, Petersen PM, Rorth M. Surveillance in stage I testicular cancer. Apmis 2003;111:76-83

11. Aparicio J, Germa JR, Garcia del Muro $X$, et al. Risk-adapted management for patients with clinical stage I seminoma: the Second Spanish Germ Cell Cancer Cooperative Group Study. J Clin Oncol 2005:23:8717-8723

12. Oliver RT, Mason MD, Mead GM, et al. Radiotherapy versus single-dose carboplatin in adjuvant treatment of stage I seminoma: a randomised trial. Lancet 2005;366:293-300

제 1 병기 성인 고환 정상피종에 대한 임상적 고찰 및 치료결과 분석

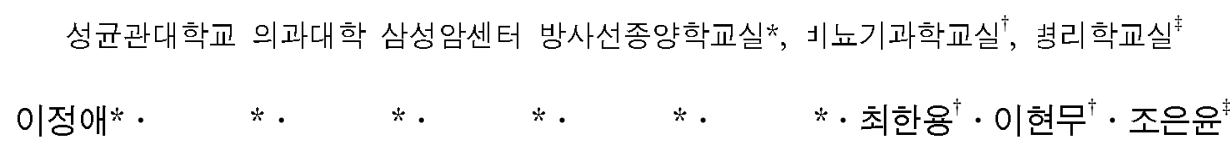

목 적: 제 1 병기 성인 고환 정상피종 환자에 대한 임상적 고찰과 함께 근치적 고환절제술 후 보조적 방사선 치료 와 고환절제술 단독치료의 결과를 후향적으로 분석 비교하고자 하였다.

대상 및 방법: 1996년 1월부터 2005년 9월까지 삼성서울병원에서 제 1 병기 정상피종으로 진단을 받은 환자 32명 의 순수 정상피종(pure seminoma) 환자를 대상으로 하였다. 근치적 고환절제술 후 22명은 보조적 방사선 치료를 시행하였고, 10 명은 추가치료 없이 종양표지자와 복부골반 전산화단층촬영을 이용한 정기적 추적관찰을 행하였 다. 방사선 치료는 10 15 MV 광자선을 사용하였으며 일일치료선량 1.8 2 Gy로 총 24 30.6 Gy (중앙값, 25.2 $\mathrm{Gy})$ 를 대동맥주위림프절(L1 L5)에 이문조사하였다. 전체 추적관찰기간은 근치적 고환절제술 시행일을 기준으로 24 155개월(중앙값, 96 개월)이었다.

결 과: 환자의 연령은 22 58세(중앙값 34세)였고, 임상적으로 진단 전 주증상은 음낭 종괴 및 불편감이 대부분이 었다. 이중 2 명에서 잠복고환의 병력이 있었으며, 병리적으로 32 명 중 23 명에서 정상피종에 관내배아세포종 (intratubular germ cell neoplasia)이 동반되어 있었다. 술후 보조적 방사선 치료를 시행한 군은 분석시점에 모든 환 자가 무병상태로 $100 \%$ 의 국소제어율 및 생존율을 보였다. 술후 추적관찰만을 시행한 군은 10 명 중 1 명에서 좌측 대동맥주위 림프절에 재발하여 구제 항암화학요법 후 완전관해되었으며 국소제어율 $88.9 \%$, 생존율 $100 \%$ 를 보였다. 결 론: 제 1 병기 정상피종에서 근치적 고환절제술 후 보조적 방사선 치료를 시행한 군과 추적관찰만을 시행한 군 간에 생존율의 차이는 없었다. 환자수가 적고 추적관찰기간이 짧기는 하지만 재발 후 항암화학요법으로 구제가 잘 되고, 방사선 치료시 이차암의 가능성이 있음을 고려한다면 정기적인 추적관찰이 가능한 환자에서 수술 후 방사선 치료를 생략할 수도 있겠다.

핵심용어: 정상피종, 근치적 고환절제술, 방사선 치료, 정기적 추적관찰 